\title{
Karakteristik Fisik, Mekanik dan Zona Hambat Edible Film Dari Pati Singkong Karet (Manihot glaziovii) Dengan Penambahan Gliserol dan Ekstrak Jahe Merah (Zingiber officinale Var Rubrum) Sebagai Penghambat Bakteri Salmonella
}

\author{
Lady Agitasi Amrillah1, Warkoyo ${ }^{1}$, Desiana Nuriza Putri 1* \\ ${ }_{1}^{1}$ Program Studi Ilmu dan Teknologi Pangan, Fakultas Pertanian Peternakan Universitas \\ Muhammadiyah Malang, Malang, Indonesia \\ *Corresponding author email :desiana@umm.ac.id
}

\begin{abstract}
Edible film is one of the innovations used to overcome food packaging problem. Components of edible films are hydrocolloids, lipids, and composites. Glycerol belongs to the hydrocolloid group which serves to maintain the solidity of the film sheet. Edible active film allegedly can inhibit physical, chemicals, and microbiology problems in the packaging which will affect the decline of food quality during storage. With the active compounds contained in red ginger it is expected to inhibit the growth of Salmonella bacteria. The purpose of this study was to determine the effect of the addition of different concentrations of glycerol and red ginger extract on the physical, mechanical and inhibitory zones in the resulting edible film produced. This research used nested design with 2 factors. The first factor was the addition of $20 \%$ glycerol concentration; 25\%; 30\% while the second factor is the addition of $0 \%$ red ginger extract; $0.5 \% ; 1 \%$; $1.5 \%$. The treatments were 12 treatments with 3 replications. The parameters of this study include thickness, tensile strength, elasticity, WVTR, transparency, moisture content, solubility, density, and edible inhibition zone against Salmonella bacteria. The results showed that edible active red ginger film with the addition of glycerol had significant effect on thickness, transparency, tensile strength and inhibition zone. On the addition of red ginger extract $1.5 \%$ can inhibit the growth of Salmonella bacteria up to $34.17 \mathrm{~mm}$.
\end{abstract}

Keywords: edible film, glycerol, red ginger extract, Salmonella bacteria.

\section{PENDAHULUAN}

Edible film merupakan salah satu pengemas alternatif yang ramah lingkungan karena terbuat dari bahan alami. Edible film dapat berfungsi sebagai pelindung bahan pangan dari bahaya fisik, kimiawi maupun mikrobiologis. Bahan utama pembuatannya umumnya dibuat dari karbohidrat, protein atau lemak. Salah satu bahan utama yang digunakan untuk membuat edible film yaitu pati. Pati dapat diperoleh dari tanaman pangan, salah satunya singkong. Singkong karet memiliki kadar pati yang cukup tinggi jika dibandingan dengan tanaman penghasil pati lainnya, sehingga memungkinkan 
untuk digunakan sebagai bahan pembuatan edible film. Komponen penyusun pati adalah amilosa dan amilopektin, dimana keduanya akan sangat berperan dalam sifat fisik dan mekanik yang akan dihasilkan oleh edible film. Menurut Guilbert dan Biquet (1990) dalam Yulianti dan Erliana (2012), kestabilan edible film dipengaruhi oleh amilopektin, sedangkan amilosa berpengaruh terhadap kekompakannya. Pati dengan kadar amilosa tinggi menghasilkan edible film yang lentur dan kuat.

Edible film yang hanya tersusun dari pati akan menghasilkan film yang rapuh sehingga dibutuhkan agen plasticizer yang nantinya dapat memperbaiki sifat mekaniknya. Gliserol termasuk salah satu agen plasticizer. Gliserol bersifat hidrofilik, sehingga cocok untuk bahan pembentukan film yang bersifat hidrofobik seperti pati. Ia dapat meningkatkan penyerapan molekul polar seperti air. Menurut Tamaela dan Sherly (2007), Plasticizer seperti gliserol, sorbitol dan polietilen glikol memiliki viskositas rendah yang bila ditambahkan akan memberikan sifat fleksibilitas.

Untuk melindungi bahan pangan dari bahaya mikrobia terutama yang bersifat patogen, perlu ditambahkan senyawa aktif pada edible film sehingga dapat mencegah pertumbuhan bakteri patogen yang merugikan. Senyawa fenol merupakan salah satu dari senyawa yang dapat berfungsi sebagai antibakteri. Senyawa fenol juga terdapat pada jahe merah (Zingiber officinale var Rubrum). Penelitian ini menggunakan pati singkong karet dengan penambahan gliserol serta ekstrak jahe merah sebagai zat bioaktif yang diharapkan dapat menghambat pertumbuhan Salmonella typhimurium.

\title{
METODE PENELITIAN
}

\section{Bahan}

Bahan- bahan yang digunakan pada penelitian ini adalah, singkong karet dengan tingkat kematangan yang cukup (umur panen 14 bulan) didapatkan dari Desa Sari Mulyo Kecamatan Jombang Kabupaten Jember, jahe merah (umur panen 10 bulan) didapat dari Desa Dawuhan Lor Kecamatan Sukodono Kabupaten Lumajang, Jawa Timur.

\begin{abstract}
Alat
Alat- alat yang digunakan pada penelitian ini antara lain cabinet dryer, ayakan ukuran 80 mesh, blender, timbangan analitik, evaporator, freezer, , oven pengering, loyang plastik $20 \mathrm{~cm} \times 28 \mathrm{~cm}$, plastik pp (polyprophylene), texture analyzer (shimizuLAF (laminar air flow), spectrophotometer, inkubator, autoclave.
\end{abstract}




\section{Pembuatan Pati Singkong}

Proses pembuatan pati singkong dimulai dari sortasi untuk memisahkan antara yang layak digunakan serta yang tidak. Singkong yang sudah disortir kemudian dikupas kulitnya dan dibersihkan dari kotoran- kotoran yang menempel dengan cara dicuci dengan air bersih. Selanjutnya dihaluskan dengan alat paruttradisional, pemarutan dilakukan untuk memudahkan pada proses ekstraksi pati.

Hasil parutan yang sudah siap ditambahkan aquades dengan perbandingan 5:1 dari jumlah singkong. Kemudian disaring untuk memisahkan ampas singkong dengan filtrat. Hasil dari penyaringan kemudian diendapkan selama 24 jam dan air endapan dibuang. Endapan pati dicuci 3 kali untuk menghilangkan kotoran- kotoran yang ada dipermukaan endapan. Proses selanjutnya yaitu pengeringan menggunakan pengering kabinet yang sudah diatur dengan suhu $55^{\circ} \mathrm{C}$, selama 12 jam. Setelah kering endapan tersebut dihaluskan dengan menggunakan blender dan diayak menggunakan ayakan 80 mesh (Sutrisno, 2009).

\section{Pembuatan Ekstrak Jahe Merah}

Ekstrak jahe merah dibuat dengan cara membersihkan jahe sebanyak 1 $\mathrm{kg}$. Kemudian dipotong tipis $\pm 5 \mathrm{~mm}$ dikeringkan dengan pengering kabinet suhu $50^{\circ} \mathrm{C}$ selama 15 jam lalu dihancurkan dengan menggunakan blender dan diayak dengan ayakan 80 mesh. Serbuk yang sudah didapat ditimbang sebanyak $100 \mathrm{~g}$, ditambahkan etanol 96\% sebanyak $400 \mathrm{ml}$ ke dalam erlenmeyer lalu digojok selama 5 menit dan diendapkan (24-72 jam) dengan sesekali digojok lagi. Hasil endapan disaring dengan menggunakan kertas whatman no 42 dengan dibantu alat pompa vakum. Ekstrak yang didapatkan kemudian diuapkan dengan menggunakan evaporator hingga didapatkan ekstrak kental. Kemudian disimpan pada refrigerator hingga saat akan digunakan (Kusuma, 2015 modifikasi).

\section{Pembuatan Edible film}

Edible film dibuat dengan mencetak $100 \mathrm{ml}$ larutan film dengan pati singkong 4,5 g dan variasi jumlah gliserol (20\%; 25\%; 30\%) serta variasi ekstrak jahe merah $(0 \% ; 0,5 \% ; 1 \% ; 1,5 \%)$. Larutan edible film aktif disiapkan dengan dicampurnya pati singkong dengan aquades, gliserol (sesuai perlakuan), kemudian dipanaskan diatas stirer hotplate sampai mencapai suhu $85^{\circ} \mathrm{C}$, dipertahankan selama 5 menit, larutan didinginkan hingga suhu $40^{\circ} \mathrm{C}$ ditambahkan ekstrak jahe merah (sesuai perlakuan). Larutan edible film yang diperoleh dituang dalam plat kaca, selanjutnya dilakukan pengeringan dengan oven pada suhu $50^{\circ} \mathrm{C}$ selama 24 jam (Warkoyo, 2014 modifikasi). Pengeringan dihentikan setelah film mudah dilepas dari plat. Setelah kering, film 
didinginkan pada suhu ruang selama 15 menit. Lapisan film dilepas dari plat plastik dan selanjutnya dianalisis sifat fisik, mekanik, serta antibakterinya.

\section{Parameter Penelitian}

Pembuatan pati dari singkong dengan menggunakan jenis singkong karet. Kemudian dilakukan analisa kimianya antara lain kadar air, kadar pati, kadar amilosa dan kadar amilopektin terhadap pati yang telah dihasilkan.

Sedangkan parameter yang diamati di Edible Film meliputi kuat tarik, elastisitas, ketebalan, laju transmisi uap air (WVTR), kelarutan, densitas, transparansi, kadar air serta pengukuran zona hambat untuk mengetahui efektivitas jahe merah sebagai penghambat Salmonella.

\section{Rancangan Percobaan dan Analisa Data}

Penelitian ini menggunakan nested design atau desain tersarang dengan 2 faktor, faktor 1 penambahan gliserol (20\%; 25\%; 30\%) dan faktor 2 penambahan ekstrak jahe merah $(0,5 \% ; 1 \% ; 1,5 \%)$. Diperoleh 12 kombinasi perlakuan dengan 3 kali ulangan. Data dianalisa dengan Analisa Ragam kemudian dilanjutkan dengan uji DMRT taraf $\alpha=5 \%$.

\section{HASIL DAN PEMBAHASAN}

\section{Analisa Bahan Baku}

Hasil analisa kimia bahan baku disajikan pada Tabel 1 dengan dibandingkan oleh literatur yang ada. Berdasarkan Tabel 1 kandungan kimia dari bahan baku berbeda dengan yang ditunjukkan oleh literatur, pada literatur kandungan patinya lebih tinggi dibandingkan bahan baku penelitian. Hal ini dapat dikarenakan faktor perlakuan pada tanaman singkong yang kemungkinan berbeda. Menurut Ginting dkk. (2005) dimana kadar pati dipengaruhi oleh jenis/ klon, umur panen optimum masing-masing umbi, dan kondisi cuaca pada saat panen. Semakin cepat atau semakin lama tanaman dipanen dari umur panen optimum semakin rendah kadar pati umbinya.

Tabel 1. Hasil Analisa Kimia Singkong Karet

\begin{tabular}{lcc}
\hline & Singkong Karet & Literatur * \\
\hline Kadar Air (\%) & 6,65 & 7,8 \\
Pati (\%) & 81,76 & 85,4 \\
Amilosa (\%) & 24,49 & 32,3 \\
Amilopektin (\%) & 57,27 & 53,1 \\
\hline
\end{tabular}

Sumber: *Yulianti (2012) 
Secara struktural, amilopektin terbentuk dari rantai glukosa yang terikat dengan ikatan 1,4 glikosidik, sama dengan amilosa. Namun demikian, pada amilopektin terbentuk cabang-cabang (sekitar tiap 20 mata rantai glukosa) dengan ikatan 1,6-glikosidik. Amilopektin tidak larut dalam air (Guilbert dan Biquet, 1990 dalam Yulianti dan Erliana, 2012). Kandungan amilosa dan amilopektin yang ada pada pati akan mempengaruhi karakter fisik dan mekanik dari edible film yang dihasilkan. Film yang lentur dan kuat dapat dibuat dari pati yang mengandung amilosa dan dalam pembentukan edible film, amilopektin memberikan stabilitas dan elastisitas (Putra, 2013).

\section{Kadar Air Edible Film}

Hasil analisis ragam menunjukkan bahwa perlakuan dengan penambahan gliserol berpengaruh tidak nyata terhadap kadar air edible film aktif jahe merah.

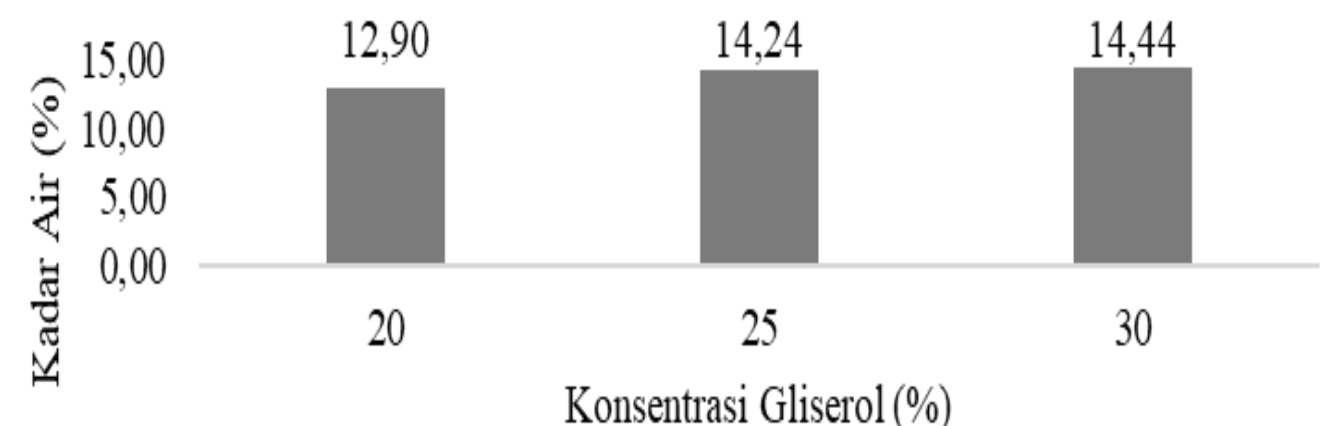

Gambar 1. Histogram Kadar Air (\%) Penambahan Gliserol dengan Konsentrasi yang Berbeda.

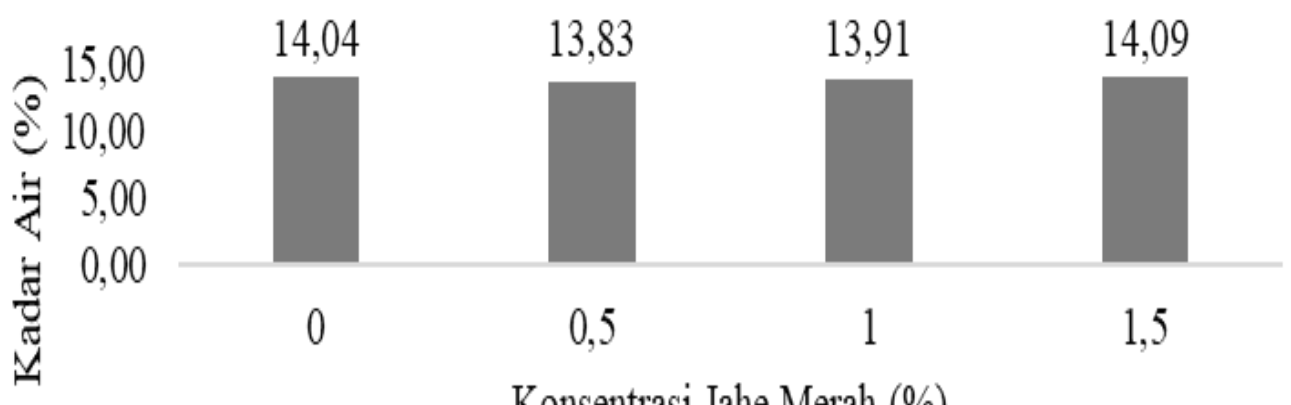

Konsentrasi Jahe Merah (\%)

Gambar 2. Histogram Kadar Air (\%) Penambahan Ekstrak Jahe Merah dengan Konsentrasi yang Berbeda.

Berdasarkan Gambar 1 nilai kadar air yang ditunjukkan memiliki perbedaan dengan pendapat literatur, hal ini dapat disebabkan oleh penambahan gliserol antar perlakuan yang selisihnya tidak terlalu besar, sehingga nilai kadar air yang dihasilkan menunjukkan nilai yang tidak signifikan. Menurut Hendra dkk. (2015) Gliserol merupakan plasticizer yang 
memiliki gugus $\mathrm{OH}$, dimana gugus $\mathrm{OH}$ tersebut bersifat hidrofilik yaitu memiliki kemampuan mengikat air. Jadi, semakin rendah konsentrasi gliserol mengakibatkan air yang terikat pada matriks edible film semakin rendah, sehingga kadar air edible film rendah pula.

Berdasarkan Gambar 2 rerata kadar air edible film aktif karena penambahan ekstrak jahe merah dalam gliserol berpengaruh tidak nyata terhadap kadar airnya. Menurut Ilah (2015), fenol mempunyai sifat larut dalam air karena dapat membentuk ikatan hidrogen dalam air. Penambahan konsentrasi ekstrak pada edible film berpengaruh terhadap meningkatnya kadar air edible film dikarenakan fenol yang terkandung pada ekstrak membentuk ikatan hidrogen dalam air. Pada masing- masing perlakuan penambahan ekstrak jahe merah selisihnya tidak terlalu besar sehingga fenol yang mengikat air dalam edible film tidak bersilisih terlalu tinggi sehingga nilai kadar air yang dihasilkan tidak berbeda secara signifikan.

\section{Densitas Edible Film}

Hasil analisis ragam menunjukkan bahwa perlakuan dengan penambahan gliserol berpengaruh tidak nyata terhadap densitas edible film aktif jahe merah.

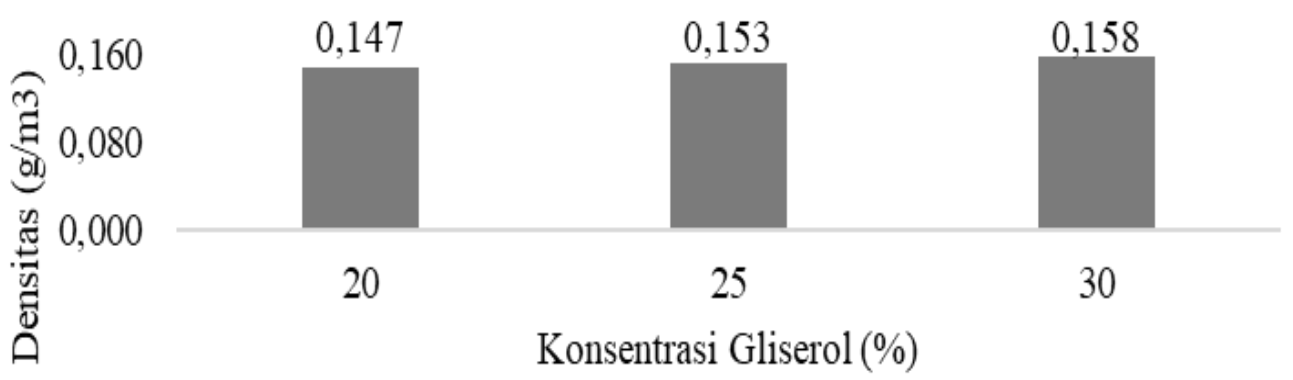

Gambar 3. Histogram Densitas $\left(\mathrm{g} / \mathrm{m}^{3}\right)$ Penambahan Gliserol dengan Konsentrasi yang Berbeda.

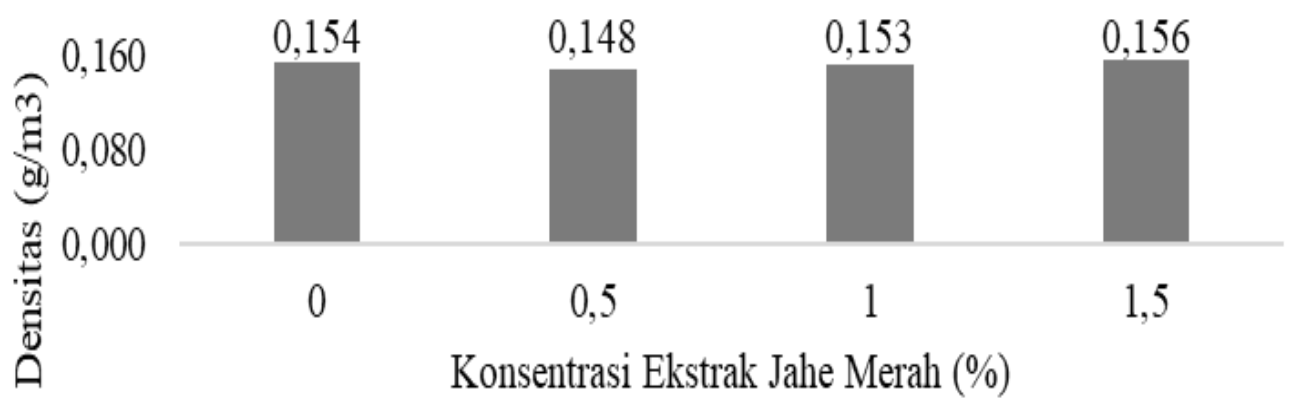

Gambar 4. Diagram Densitas $\left(\mathrm{g} / \mathrm{m}^{3}\right)$ Penambahan Ekstrak Jahe Merah dengan Konsentrasi yang Berbeda. 
Berdasarkan Gambar 3 perlakuan edible film dengan penambahan gliserol nilai rerata densitasnya tidak berbeda nyata, hal ini dapat dikarenakan massa yang dimiliki oleh bahan tidak berselisih terlalu jauh mengingat jumlah gliserol yang ditambahkan tidak selisih banyak. Sedangkan pada Gambar 4 edible film dengan penambahan jahe merah dalam gliserol menunjukkan hal yang serupa yaitu tidak berpengaruh nyata. Ekstrak jahe merah yang ditambahkan pada edible film akan membuat bahan aktif yang didapatkan dari ekstrak jahe meningkatkan jumlah padatan terlarut dari edible film tersebut sehingga meningkatkan massa dari edible film tersebut. Menurut Widyaningsih dkk. (2012), densitas berbanding lurus dengan massa suatu bahan, sehingga semakin besar massa suatu bahan maka nilai densitas semakin besar.

\section{Ketebalan Edible Film}

Hasil analisis ragam menunjukkan bahwa perlakuan dengan penambahan gliserol dan jahe merah berpengaruh nyata terhadap ketebalan edible film. Berdasarkan Tabel 2 nilai ketebalan berkisar antara $0,161 \mathrm{~mm}^{-}$0,347mm. Semakin tinggi gliserol dan ekstrak jahe merah yang ditambahkan menunjukkan semakin meningkat nilai ketebalannya. Hal ini dapat dikarenakan semakin tinggi penambahan gliserol dan ekstrak jahe merah maka semakin menambah padatan terlarut pada edible film sehingga massanya bertambah yang menyebabkan meningkatnya nilai ketebalan film.

Tabel 2 Rerata Ketebalan Edible Film Aktif Jahe Merah

\begin{tabular}{ll}
\hline Kombinasi Perlakuan & $\begin{array}{l}\text { Ketebalan } \\
(\mathrm{mm})\end{array}$ \\
\hline G1F0 (Gliserol 20\% + Ekstrak Jahe merah 0\%) & $\begin{array}{l}0,161 \mathrm{a} \\
0,260 \mathrm{c}\end{array}$ \\
G1F1 (Gliserol 20\% + Ekstrak Jahe merah 0,5\%) & $0,328 \mathrm{~d}$ \\
G1F2 (Gliserol 20\% + Ekstrak Jahe merah 1\%) & $0,182 \mathrm{ab}$ \\
G1F3 (Gliserol 20\% + Ekstrak Jahe merah 1,5\%) & $0,236 \mathrm{c}$ \\
G2F0 (Gliserol 25\% + Ekstrak Jahe merah 0\%) & $0,256 \mathrm{c}$ \\
G2F1 (Gliserol 25\% + Ekstrak Jahe merah 0,5\%) & $0,251 \mathrm{c}$ \\
G2F2 (Gliserol 25\% + Ekstrak Jahe merah 1\%) & $0,241 \mathrm{c}$ \\
G2F3 (Gliserol 25\% + Ekstrak Jahe merah 1,5\%) & $0,234 \mathrm{bc}$ \\
G3F0 (Gliserol 30\% + Ekstrak Jahe merah 0\%) & $0,234 \mathrm{c}$ \\
G3F1 (Gliserol 30\% + Ekstrak Jahe merah 0,5\%) & $0,263 \mathrm{c}$ \\
G3F2 (Gliserol 30\% + Ekstrak Jahe merah 1\%) & $0,347 \mathrm{~d}$ \\
G3F3 (Gliserol 30\% + Ekstrak Jahe merah 1,5\%)
\end{tabular}

Keterangan : Angka-angka yang diikuti oleh huruf yang tidak sama menunjukkan perbedaan yang nyata menurut uji Duncan a 5\% 
Hasil penelitian Warkoyo dkk., (2014), Ketebalan edible film cenderung meningkat dengan bertambahnya kalium sorbat yang diberikan. Pertambahan bahan aktif dapat menyebabkan kerapatan molekul berkurang, ruang bebas yang terbentuk pada matriks film semakin besar, akibatnya film yang terbentuk semakin tebal. Bourtoom (2006), mengatakan bahwa plasticizer dapat berikatan dengan pati membentuk polimer pati-plasticizer. Ikatan antara pati dengan pati digantikan dengan ikatan antara pati-gliserol-pati sehingga ketebalan meningkat seiring dengan bertambahnya konsentrasi gliserol dalam pasta film.

\section{Kelarutan Edible Film}

Hasil analisis ragam menunjukkan bahwa perlakuan dengan penambahan gliserol berpengaruh tidak nyata terhadap kelarutan edible film aktif jahe merah.

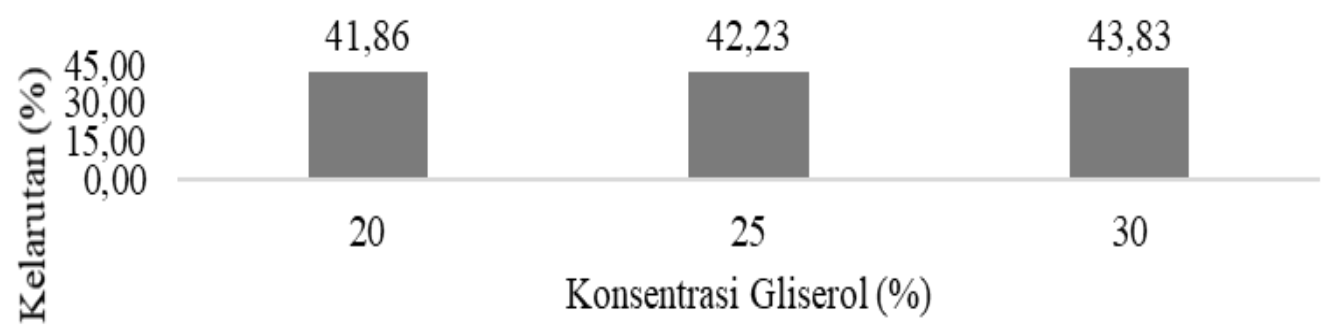

Gambar 5. Histogram Kelarutan (\%) Penambahan Gliserol dengan Konsentrasi yang Berbeda.

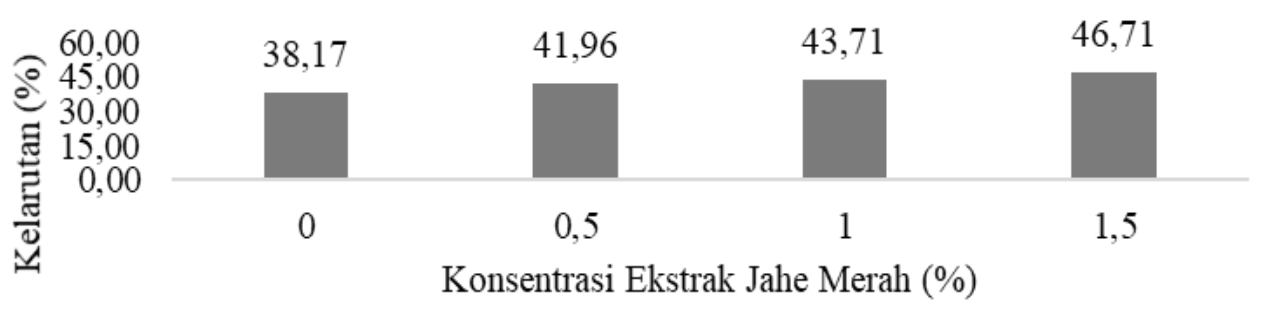

Gambar 6. Histogram Kelarutan (\%) Penambahan Ekstrak Jahe Merah dengan Konsentrasi yang Berbeda.

Berdasarkan Gambar 5, nilai kelarutannya bekisar antara 41,86\%43,83\%. Nilai kelarutan digunakan untuk menunjukkan ketahanan suatu film terhadap air. Gliserol yang ditambahkan akan menambah ikatan hidroksil sehingga semakin banyak air yang akan terikat dengan semakin besarnya penambahan gliserol pada edible film. Sedangkan pada Gambar 6 nilai kelarutan edible film dengan penambahan ekstrak jahe merah dalam gliserol berkisar 
38,17\%- 46,71\%. Hal ini dikarenakan ekstrak jahe merah termasuk kedalam golongan hidrokoloid, dimana hidrokoloid ini bertugas untuk larut dalam air pada bahan sehingga semakin meningkatnya penambahan ekstrak jahe merah maka akan meningkatkan pula nilai kelarutannya. Menurut Nugroho dkk. (2013), kelarutan dipengaruhi oleh komponen hidrofilik dan hidrofob. Semakin tinggi nilai hidrofilik suatu bahan maka kelarutannya akan semakin tinggi, dan semakin tinggi nilai hidrofob suatu bahan maka kelarutannya akan semakin rendah.

\section{Transparansi Edible Film}

Hasil analisis ragam menunjukkan bahwa perlakuan dengan penambahan gliserol dan jahe merah berpengaruh nyata terhadap transparansi edible film. Berdasarkan Tabel 3 hasil transparansi dengan penambahan gliserol dan jahe merah menunjukkan bahwa semakin tinggi konsentrasi jahe merah yang ditambahkan maka nilai transparansinya semakin tinggi.

Tabel 3 Rerata Transparansi Edible Film Aktif Ekstrak Jahe Merah

\section{Transparansi}

Kombinasi Perlakuan (A $546 / \mathrm{mm})$

G1F0 (Gliserol 20\% + Ekstrak Jahe merah 0\%) 1,197a

G1F1 (Gliserol 20\% + Ekstrak Jahe merah 0,5\%) 2,933cd

G1F2 (Gliserol 20\% + Ekstrak Jahe merah 1\%) 2,799cd

G1F3 (Gliserol 20\% + Ekstrak Jahe merah 1,5\%) 2,712cd

G2F0 (Gliserol 25\% + Ekstrak Jahe merah 0\%) 1,485ab

G2F1 (Gliserol 25\% + Ekstrak Jahe merah 0,5\%) 2,044abc

G2F2 (Gliserol 25\% + Ekstrak Jahe merah 1\%) 2,724cd

G2F3 (Gliserol 25\% + Ekstrak Jahe merah 1,5\%) 3,253d

G3F0 (Gliserol 30\% + Ekstrak Jahe merah 0\%) 1,197a

G3F1 (Gliserol 30\% + Ekstrak Jahe merah 0,5\%) 2,672cd

G3F2 (Gliserol 30\% + Ekstrak Jahe merah 1\%) 2,758cd

G3F3 (Gliserol 30\% + Ekstrak Jahe merah 1,5\%) 2,350bcd

Keterangan : Angka-angka yang diikuti oleh huruf yang tidak sama menunjukkan perbedaan yang nyata menurut uji Duncan a 5\%

Nilai rata- rata transparansi yang dihasilkan berkisar antara 1,197 $\mathrm{A}_{546} / \mathrm{mm}-$ $3,253 \mathrm{~A}_{546} / \mathrm{mm}$. Nilai yang dihasilkan berbanding terbalik dengan sifat transparansi, nilai yang semakin tinggi menunjukkan bahwa film tersebut semakin tidak transparan atau semakin keruh. Fenomena ini serupa dengan penelitian Warkoyo dkk., (2014), Transparansi cenderung meningkat seiring 
dengan meningkatnya konsentrasi bahan aktif, artinya dengan semakin besar konsentrasi kalium sorbat yang ditambahkan maka derajat transparansi (kejernihan) cenderung menurun.

\section{Kuat Tarik Edible Film}

Hasil analisis ragam menunjukkan bahwa perlakuan dengan penambahan gliserol dan jahe merah berpengaruh nyata terhadap kuat tarik edible film.

Berdasarkan Tabel 4 nilai kuat tarik edible film berkisar antara 0,121 $\mathrm{MPa}^{-}$0,251 MPa. Semakin meningkatnya penambahan gliserol nilai kuat tariknya juga ikut meningkat serta ditambahkannya ekstrak jahe merah juga mempengaruhi nilai kuat tariknya. Hal ini dapat dikarenakan dengan ditambahkannya gliserol dan ekstrak jahe merah maka total padatan terlarut semakin besar dan nilai kuat tarik berbanding lurus dengan ketebalan, semakin tebal suatu edible film maka semakin besar pula gaya yang dibutuhkan untuk memutus edible tersebut. Berdasarkan Japanese Industrial Standart (1975) menyebutkan bahwa nilai standart minimal nilai kuat tarik edible film 0,392266 MPa. Menurut Dallan et al. (2006), semakin banyak komponen hidrokoloid penyusun film akan menyebabkan kuat tariknya semakin meningkat. Hal ini dikarenakan akan semakin banyak interaksi hidrogen yang terdapat dalam edible film sehingga ikatan antar rantai akan semakin kuat dan sulit untuk diputus karena memerlukan energi yang besar untuk memutus ikatan tersebut.

Tabel 4 Rerata Kuat Tarik Edible Film Aktif Ekstrak Jahe Merah

\begin{tabular}{ll}
\hline Kombinasi Perlakuan & Tensile (MPa) \\
\hline G1F0 (Gliserol 20\% + Ekstrak Jahe merah 0\%) & $0,192 \mathrm{bcd}$ \\
G1F1 (Gliserol 20\% + Ekstrak Jahe merah 0,5\%) & $0,147 \mathrm{ab}$ \\
G1F2 (Gliserol 20\% + Ekstrak Jahe merah 1\%) & $0,121 \mathrm{a}$ \\
G1F3 (Gliserol 20\% + Ekstrak Jahe merah 1,5\%) & $0,176 \mathrm{abcd}$ \\
G2F0 (Gliserol 25\% + Ekstrak Jahe merah 0\%) & $0,150 \mathrm{ab}$ \\
G2F1 (Gliserol 25\% + Ekstrak Jahe merah 0,5\%) & $0,222 \mathrm{de}$ \\
G2F2 (Gliserol 25\% + Ekstrak Jahe merah 1\%) & $0,155 \mathrm{abc}$ \\
G2F3 (Gliserol 25\% + Ekstrak Jahe merah 1,5\%) & $0,163 \mathrm{abc}$ \\
G3F0 (Gliserol 30\% + Ekstrak Jahe merah 0\%) & $0,193 \mathrm{bcd}$ \\
G3F1 (Gliserol 30\% + Ekstrak Jahe merah 0,5\%) & $0,202 \mathrm{bcde}$ \\
G3F2 (Gliserol 30\% + Ekstrak Jahe merah 1\%) & $0,251 \mathrm{e}$ \\
G3F3 (Gliserol 30\% + Ekstrak Jahe merah 1,5\%) & $0,209 \mathrm{cde}$ \\
\hline Keterangan
\end{tabular}

Keterangan : Angka-angka yang diikuti oleh huruf yang tidak sama menunjukkan perbedaan yang nyata menurut uji Duncan a 5\% 


\section{Perpanjangan Edible Film}

Hasil analisis ragam menunjukkan bahwa perlakuan dengan penambahan gliserol berpengaruh tidak nyata terhadap perpanjangan edible film aktif jahe merah.

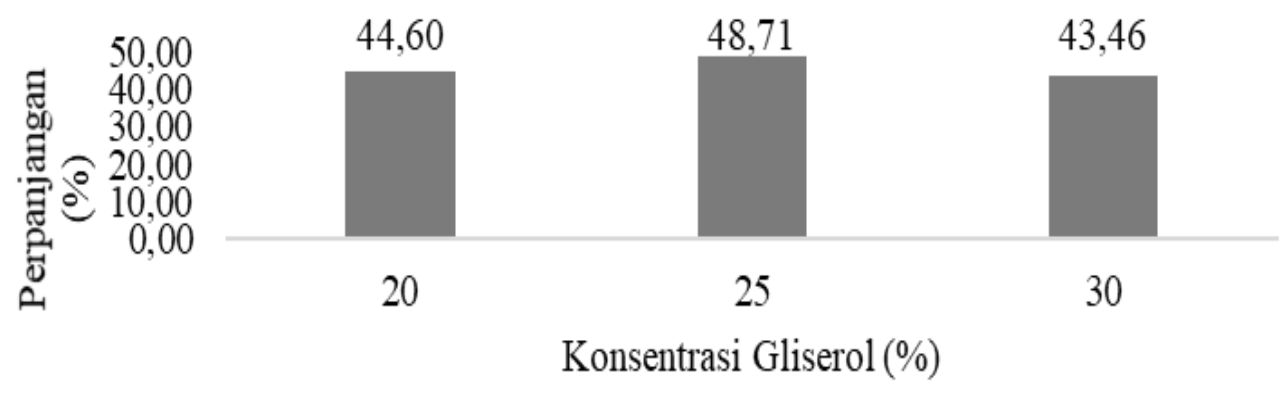

Gambar 7. Diagram Perpanjangan (\%) Penambahan Gliserol dengan Konsentrasi yang Berbeda.

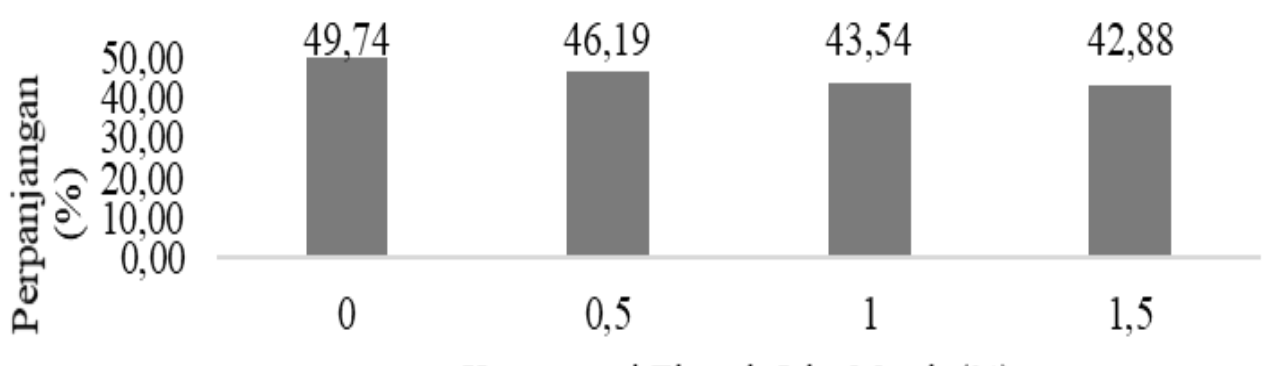

Konsentrasi Ekstrak Jahe Merah (\%)

Gambar 8. Diagram Perpanjangan (\%) Penambahan Ekstrak Jahe Merah dalam Gliserol dengan Konsentrasi yang Berbeda.

Berdasarkan Gambar 7 nilai perpanjangan yang dihasilkan dari edible film aktif jahe merah menunjukkan nilai yang tidak jauh berbeda. Hal ini dapat dikarenakan konsentrasi penambahan gliserol pada masing- masing perlakuan edible film tidak berselisih banyak sehingga nilai perpanjangan yang dihasilkan tidak jauh beda antara satu sama lain. Gliserol merupakan salah satu agen penyusun edible film yang akan mengokohkan struktur penyusun film, sehingga film tidak rapuh dan tidak mudah robek. Selain itu dengan ditambahkan gliserol film yang dihasilkan akan lebih elastis.

Pada Gambar 8 nilai perpanjangan edible film karena penambahan ekstrak jahe merah berkisar antara 42,88\%-49,74\%. Berdasarkan nilai analisis perpanjangan edible film aktif jahe merah menunjukkan nilai yang sama namun tergolong memiliki nilai yang tinggi. Menurut Pramadita (2010), Penambahan minyak atsiri kayu manis membuat nilai perpanjangan cenderung semakin turun. Semakin banyak minyak yang ditambahkan maka matrik film yang 
terbentuk akan lebih rapuh karena minyak memiliki ikatan antar senyawa yang lemah.

\section{Laju Transmisi Uap Air/ Water Vapor Transmission Rate (WVTR)}

Hasil analisis ragam menunjukkan bahwa perlakuan dengan penambahan gliserol berpengaruh nyata terhadap WVTR edible film.

Tabel 5. Rerata WVTR Edible Film Aktif Ekstrak Jahe Merah

\begin{tabular}{lc}
\hline Konsentrasi Gliserol (\%) & WVTR (g/m²/24jam) \\
\hline 20 & $30,37 \mathrm{a}$ \\
25 & $38,43 \mathrm{~b}$ \\
30 & $38,36 \mathrm{~b}$ \\
\hline
\end{tabular}

Keterangan : Angka-angka yang diikuti oleh huruf yang tidak sama menunjukkan perbedaan yang nyata menurut uji Duncan a $5 \%$

Berdasarkan Tabel 5 nilai WVTR dari edible film jahe merah berkisar antara $30,37-38,43 \mathrm{~g} / \mathrm{m}^{2} / 24 \mathrm{jam}$. Gliserol yang ditambahkan pada edible akan membuat terisinya rongga- rongga matriks yang ada pada edible film tersebut sehingga menjadikan matriksnya lebih rapat yang menyebabkan sulit ditembus oleh uap air yang ada, selain itu ketebalan edible film ikut mempengaruhi nilai WVTR nya.

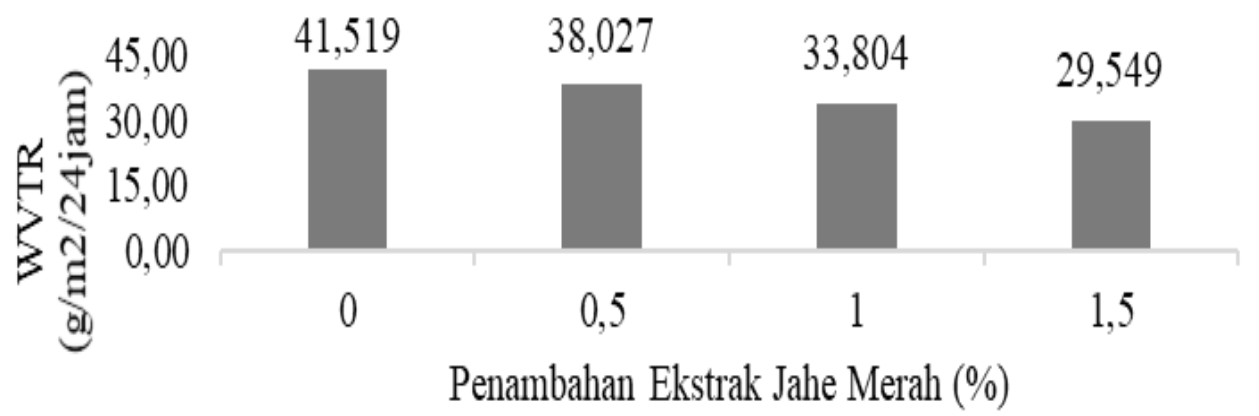

Gambar 9. Diagram WVTR ( $\left.\mathrm{g} / \mathrm{m}^{2} / 24 \mathrm{jam}\right)$ Penambahan Ekstrak Jahe Merah dalam Gliserol dengan Konsentrasi yang Berbeda.

Berdasarkan Gambar 9 hasil analisa WVTR karena penambahan konsentrasi ekstrak jahe merah dalam gliserol menunjukkan hasil yang tidak berpengaruh nyata terhadap nilai WVTR nya. Hal ini dapat dikarenakan penambahan ekstrak jahe yang memiliki selisih yang kecil sehingga nilai dari WVTR yang dihasilkan tidak berselisih terlalu jauh. Beberapa peneliti berpendapat bahwa, semakin rendah nilai laju transmisi uap air maka edible film tersebut akan semakin baik (Amaliya dan Putri, 2014). Menurut Japanes Industrial Standart (1975), plastik film yang baik untuk kemasan makanan 
adalah film yang mempunyai nilai permeabilitas uap air maksimal $7 \mathrm{gr} /$ ( $\left.\mathrm{m}^{2} / \mathrm{hari}\right)$.

\section{Zona Hambat Edible Film}

Hasil analisis ragam menunjukkan bahwa perlakuan dengan penambahan gliserol dan jahe merah berpengaruh nyata terhadap zona hambat edible film.

Tabel 6 Rerata Zona Hambat Edible Film Aktif Ekstrak Jahe Merah

\begin{tabular}{ll}
\hline Kombinasi Perlakuan & Zona Hambat (mm) \\
\hline G1F0 (Gliserol 20\% + Ekstrak Jahe merah 0\%) & $12,83 \mathrm{a}$ \\
G1F1 (Gliserol 20\% + Ekstrak Jahe merah 0,5\%) & $28,33 \mathrm{bcd}$ \\
G1F2 (Gliserol 20\% + Ekstrak Jahe merah 1\%) & $26,83 \mathrm{bcd}$ \\
G1F3 (Gliserol 20\% + Ekstrak Jahe merah 1,5\%) & $32,33 \mathrm{~d}$ \\
G2F0 (Gliserol 25\% + Ekstrak Jahe merah 0\%) & $16,83 \mathrm{a}$ \\
G2F1 (Gliserol 25\% + Ekstrak Jahe merah 0,5\%) & $19,50 \mathrm{abc}$ \\
G2F2 (Gliserol 25\% + Ekstrak Jahe merah 1\%) & $29,67 \mathrm{~d}$ \\
G2F3 (Gliserol 25\% + Ekstrak Jahe merah 1,5\%) & $35,50 \mathrm{~d}$ \\
G3F0 (Gliserol 30\% + Ekstrak Jahe merah 0\%) & $18,83 \mathrm{ab}$ \\
G3F1 (Gliserol 30\% + Ekstrak Jahe merah 0,5\%) & $29,33 \mathrm{~d}$ \\
G3F2 (Gliserol 30\% + Ekstrak Jahe merah 1\%) & $28,50 \mathrm{~cd}$ \\
G3F3 (Gliserol 30\% + Ekstrak Jahe merah 1,5\%) & $34,67 \mathrm{~d}$ \\
\hline
\end{tabular}

Keterangan : Angka-angka yang diikuti oleh huruf yang tidak sama menunjukkan perbedaan yang nyata menurut uji Duncan a 5\%

Berdasarkan Tabel 6 nilai zona hambat dari edible film meningkat seiring dengan konsentrasi jahe merah yang meningkat sedangkan pada hal ini penambahan gliserol diduga tidak memiliki pengaruh terhadap zona hambat edible film terhadap bakteri Salmonella. Rerata zona hambat yang dihasilkan berkisar antara 12,83 $\mathrm{mm}^{-} 35,50 \mathrm{~mm}$. Berdasarkan hal ini dapat disimpulkan bahwa semakin tinggi penambahan konsentrasi ekstrak jahe merahnya maka semakin besar nilai zona hambat yang dihasilkan dari penanaman edible film dengan ditambahkannya bakteri Salmonella. Menurut Nursal dkk. (2006), kandungan senyawa metabolit sekunder pada tanaman jahe- jahean terutama golongan flavonoid, fenol, terpenoid dan minyak atsiri. Senyawa metabolit sekunder yang dihasilkan tumbuhan Zingiberaceae ini umumnya dapat menghambat pertumbuhan patogen yang merugikan kehidupan manusia. 


\section{KESIMPULAN}

Terjadi pengaruh pada edible film penambahan gliserol dan ekstrak jahe merah dengan konsentrasi berbeda terhadap parameter ketebalan, transparansi, kuat tarik dan zona hambat. Serta pada parameter zona hambat terhadap bakteri Salmonella menghasilkan rata- rata zona hambat yang mencapai 34,17 mm dengan penambahan ekstrak jahe merah 1,5\%.

\section{REFERENSI}

Amaliya. R.R. dan Putri, W.D.R. 2014. Karakterisasi edible flm dari pati jagung dengan penambahan fltrat kunyit putih sebagai antibakteri. Jurnal Pangan dan Agroindustri 2: 43-53.

Bourtoom T. 2006. Effect of Some Process Parameters on the Properties of Edible film Prepared from Starches. Department of Material Product Technology. Prince of Songkla University. Hat Yai.Songkhla.

Dallan, P. R. M. ; Moreira, P. Da Luz.; Petinari, L.; Malmonge, S. M.; Beppu, M. M.; Genari, S. C. And Moraes, A. M. 2006. Effects of Chitosan Solution Concentration and Incorporation of Chitin and Glycerol on Dense Chitosan Membrane Properties. Journal of Biomedical Materials Research Part B: Applied Biomaterials: 394-405.

Estiningtyas, H. R. 2010. Aplikasi Edible Film Maizena dengan Penambahan Ekstrak Jahe sebagai Antioksidan Alami pada Coating Sosis Sapi. Skripsi Fakultas Pertanian Universitas Sebelas Maret, Surakarta.

Ginting, E., Y. Widodo, St. A. Rahayuningsih, dan M. Yusuf. 2005. Karakteristik pati beberapa varietas ubi jalar. Jurnal Penelitian Tanaman Pangan 24 (1): 8-16.

Guilbert, S. and B. Biquet. 1990. Edible films and coatings. Dalam Rahmi Yulianti dan Erliana Ginting. 2012. Perbedaan Karakteristik Fisik Edible Film dari Umbi-umbian yang Dibuat dengan Penambahan Plasticizer. Jurnal Penelitian Pertanian Tanaman Pangan Vol. 31 No. 2, Halaman 131-136

Hendra, A. A., A. Rulianto U., Erni S. 2015. Kajian Karakteristik Edible Film Dari Tapioka Dan Gelatin Dengan Perlakuan Penambahan Gliserol. Fakultas Teknologi Pertanian, Universitas Katolik Widya Mandala Surabaya, Surabaya

Ilah, F. M. 2015. Pengaruh Penambahan Ekstrak Etanol Daun Salam (Eugenia polyantha) dan Daun Beluntas (Pluchea indica Less) Terhadap Sifat Fisik, Aktivitas Antibakteri dan Aktivitas Antioksidan pada Edible Film Berbasis Pati Jagung. Skripsi. Fakultas Sains dan Teknologi. Universitas Islam Negeri Maulana Malik Ibrahim. Malang

Japanese Standards Association. 1997. JIS (Japanesse Industrial Standard) Z 1707: 1997. General Rules of Plastic Films for Food Packaging. Tokyo: JSA

Kusuma, A. 2015. The Effect of Ethanol Extract of Soursop Leaves (Annona muricata L.) to Decreased Levels of Malondialdehyde. J Majority. Vol. 4. 
No. 3.Nugroho AA, Basito, Katri ARB. 2013. Study the manufacture of tapioca edible films with the effect of addition of pectin some type of in banana peels against mechanical and physical characteristics. Jurnal Teknosains Pangan 2 (1): 73-79.

Nursal, W., Sri dan Wilda S. 2006. Bioaktifitas ekstrak jahe (Zingiber officinale Roxb.) dalam menghambat pertumbuhan koloni bakteri Escherichia coli dan Bacillus subtilis. Jurnal Biogenesis, 2 (2): 64-66.

Pramadita, R. C., dan Aji S. 2010. Karakterisasi Edible Film dari Tepung Porang (Amorphophallus oncophyllus) dengan penambahan Minyak Atsiri Kayu Manis (Cinnamon Burmani) sebagai Antibakteri. Jurusan Teknologi Hasil Pertanian Fakultas Teknologi Pertanian Universitas Brawijaya. Malang

Putra, D. 2013. Formulasi Edible film sebagai Antibacterial Active Packaging dengan Penambahan Ekstrak Daun Jati (Tectona grandis). Skripsi. Jurusan Teknologi Hasil Pertanian Fakultas Teknologi Pertanian Universitas Brawijaya. Malang

Sutrisno, D. dan S. Keman. 2009 . Nilai makanan hijauan segar ketela pohon untuk ternak sapi dan kerbau. Proceedings Seminar Penelitian Peternakan Pusat Penelitian dan Pengembangan Peternakan, Bogor.

Tamaela, Pieter dan Sherly Lewerissa. 2007. Karakteristik Edible Film dari Karagenan. Ichthyos. Vol. 7, No. 1 Hal: 27

Warkoyo, B. Raharjo, D.W. Marseno, dan J.N.W. Karyadi. 2014. Sifat Fisik, Mekanik dan Barrier Edible Film Berbasis Pati Umbi Kimpul (Xanthosoma sagittifolium) yang Diinkorporasi dengan Kalium Sorbat. Jurnal Agritech, Vol. 34, No. 1, Halaman 72-81

Widyaningsih S, Kartika D, Nurhayati YT. 2012. Pengaruh penambahan sorbitol dan kalsium karbonat terhadap karakteristik dan sifat biodegradasi film dari kulit pisang. Molekul. 7(1): 69-81.

Yulianti, R. dan Erliana G. 2012. Perbedaan Karakteristik Fisik Edible Film dari Umbi-umbian yang Dibuat dengan Penambahan Plasticizer. Jurnal Penelitian Pertanian Tanaman Pangan Vol. 31 No. 2 2012. Halaman 131136 